\title{
LITERATURE
}

DOI https://doi.org/10.30525/978-9934-588-90-7-15

\section{ПРОЗА ЮРІЯ СТАНИНЦЯ ТА ІВАНА ЯЦКАНИНА: КОМПАРАТИВНО-ЕКЗИСТЕНЦИЙНЕ ПРОЧИТАННЯ}

\author{
Барчан В. В. \\ доктор філологічних наук, професор, \\ завідувач кафедри української літератури \\ Ужггородський національний університет \\ м. Ужгород, Украӥна
}

Юрій Станинець (1906-1994) - один із плеяди визначних письменників Закарпаття 20-30-х pp. XX ст., з іменем якого українське художнє слово краю утверджувалося «як мистецтво сучасне, професійне, європейське, виходило на світові обшири» [5, с. 14]. Вважаємо, що сучасність i європеїзм як важливі характеристики творчості митця вдається побачити крізь призму екзистенційного підхіду до прочитання творів Ю. Станинця й сучасного українського прозаїка Словаччини I. Яцканина.

Після виходу збірки оповідань Ю. Станинця «Подарунок» (1941) критик I. Вокович твердив, що автор може стати «руським Реймонтом, Голечеком...» [1]. Талант митця оцінили О. Мишанич, Л. Голомб, Ф. Потушняк, I. Ребрик, Н. Ребрик та ін. Аналіз творчості І. Яцканина представлений у студіях М. Романа, В. Гарянськи, О. Вертій, Я. Джоганика Т. Кобаль, О. Талабірчук та ін. Однак праць типологічного характеру щодо творчості цих митців немає.

Мета дослідження - провести компаративний аналіз прози Ю. Станинця та І. Яцканина як репрезентанта сучасного європейського тексту української белетристики, що дасть можливість констатувати властиві українській літературі Закарпаття 20-30-х рр. XX ст. тенденції, увиразнить прикмети авторського світобачення та індивідуального стилю обох митців.

Як свідчить «Автобіографія» Юрія Станинця, у його мистецькому становленні важливу роль відіграла європейська літературна школа, у якій вагоме місце зайняло і слов'янське письменство [3, с. 595].

У письменницькому досвіді Ю. Станинця, естетична свідомість якого формувалася в європейському мистецькому й філософському континуумі, привертає увагу орієнтація на осмислення загальнолюдських 
проблем. Цей вектор художнього мислення виділяє митця в літературному контексті як минулого, так і сучасного. Підтвердженням цього може бути порівняльний огляд його творчості 3 доробком Івана Яцканина, якого можна вважати продовжувачем традицій українського письменства, що утверджували на Закарпатті за роки Чехословаччини Ю. Станинець та його сучасники - Ф. Потушняк, Зореслав, О. Маркуш й ін., а в середині XX століття - I .Чендей, репрезентуючи літературу філософського звучання.

Ю. Станинець та І. Яцканин - носії однісї етноментальності, однісї світовідчуттєвої парадигми, письменники, які увійшли в літературу як автори короткого прозового жанру. Зацікавлені різними темами соціально-побутового характеру, обидва виявили себе добрими знавцями людської психології, митцями, заглибленими у філософію буття. Екзистенційні проблеми самотності, межової ситуації, смерті порушені, зокрема, у новелах «Загублені діти», «Бабина осінь» Ю. Станинця та в оповіданнях I. Яцканина - «Скрипка», «Коні вмирають вночі», «Душа в маленькому каштані», «Остання зустріч», «Асфальтовий хлопець», «Графік смерті» та ін.

Прикметно, що тема самотності найбільш глибоко розроблена в психологічних новелах Ю. Станинця. Натомість в І. Яцканина вона, як вважають дослідники, домінує у перших двох збірках [2, с. 66], але є органічною для всієї творчості [4, с. 76].

Характерно, що в обох митців поглиблена увага сфокусована переважно на долі людей старшого віку, які, закономірно, позбавлені активної суспільної комунікації, зазнали родинних втрат, відчувають тягар екзистенційної самотності. Зауважимо, що Станинцеві ближчими $\epsilon$ типажі селян, яких усамітнює і просторова віддаленість, і комунікативна обмеженість. У його творах сюжетотворчою $\epsilon$ «мова душі» героїв. I. Яцканин же увиразнює зовнішній сюжет. Його героями теж часто виступають селяни - батьки, матері, вдівці. Причиною їхньої самотності є розлука $з$ дітьми, втрата соціальної активності, пов'язаної з роботою. Разом із тим Яцканинові притаманний інтерес і до психології душі іншого типу героїв - містян, навколо яких вирує багатогранне життя. Однак персонажі збірки «...як збиті пси» [8] страждають від внутрішньої, екзистенційної самотності «внаслідок невирішеного внутрішнього конфлікту, що характеризується й відчуттям спустошеності» [4, с. 85-86]. Це мотивує в героїв роздуми про смерть, провокує пошук якихось змін, що інтерпретуються у творах через мотив утечі. «Втеча без вороття» - так називається одна зі збірок митця [9]. 
Подібне світовідчуття, коли людина - невід'ємна частка безмежного всесвіту, виражається і в новелах Ю. Станинця. Тема самотності зреалізована у двох моделях: самотність через втрату зв'язку з рідними («Загублені діти») i внутрішньоособистісна самотність, спричинена віковими змінами («Бабина осінь»).

У першій моделі мотиву самотності нерідко супровідним $є$ мотив сенсу життя або марності життя. I в Станинця («Загублені діти»), і в Яцканина («Коні вмирають вночі», «Душа в маленькому каштані» та ін.) герої старшого віку не мислять себе без праці, без користі іншим, інколи навіть допускають думки про марність своїх життєвих старань. «Лиш для кого я ие пряду?...Нащо було ціле життя так тяжко робити, так побиватися за всім, так мучитися? .. A тут, еге, є все, а їх нема» [3, с. 440], - розмірковує Катійчуканя. «Робиш, робиш, ані за тобою, ані перед, нічого не видно» [7, с. 44], - бентежиться Зубаль.

Другий варіант мотиву самотності змодельовано в новелі Ю. Станинця «Бабина осінь». Стан екзистенційної відчуженості зумовлений тут не соціальними, а природними чинниками. Це підкреслено i метафоричним виразом «бабине літо», і психологізованими деталями пейзажу: бабиного літа зі срібною вуаллю «по золотистій млаці, по стреняках опустілих полів» [3, с. 481]; дороги, вкритої опалим листям бурштинового кольору; голосом листя, яке опирається поривам вітру, але трепетно спадає й безсило стелиться до ніг.

Типологічна спорідненість творів Станинця і Яцканина помітна і в інтерпретації ними мотиву смерті. На наш погляд, твори обох митців можна вважати художніми студіями психології смерті. Художнє осмислення Станинцем цієї теми базується на Гайдеггеровій філософії про неусвідомлення людиною в повсякденному (недійсному) існуванні своєї приреченості [6, с. 291] і бажанні жити. Однак людина не лише не цінує життя, а, навпаки, своїми діями у всіх їх виявах вкорочує його. Тому бачимо, як автор відтворює різні психічні стани героїні «Загублених дітей», що супроводжуються широким спектром емоцій відстороненості, радості, захоплення, вдоволення, співчуття, жалю, гніву, люті, наростання психологічної душевної напруги аж до екстатичності, до межового відтинку.

У варіантах художнього втілення психології смерті у творах I. Яцканина постає багатоманіття авторських сценаріїв: «смерть як закономірний процес життя людини, т.зв. природна смерть, вбивство, самогубство і батьковбивство» [4, с. 102$]$.

Порівняно 3 Яцканиновими художніми виявами шляхів і станів кінцевого часу земної присутності людини, Ю.Станинець у новелі 
«Бабина осінь» зосереджується на концепті вітальності. Водночас у художній картині смерті можемо відчути суголосність Ю. Станинця 3 думками Гайдеггера про те, що «людина виривається за межі недійсного (реального, земного - В.Б.) існування, відчувши „екзистенціальний страх". Цей страх - не жах очікування чогось конкретного; в основі своїй-це страх смерті, який розкриває перед людиною нову перспективу - смерть» [6, с. 291]. Транспонуючи цю думку і на твори Яцканина, можемо побачити, що в обох авторів у художніх моделях психології смерті оприявнюються переживання героями екзистенціальної самотності, відчуженості, вибору, які $\epsilon$ вже фактично переживанням смерті, ще не фізичної, але власної екзистенції.

Отже, проведений аналіз засвідчує, що пипологічні риси у прозі двох митців різних культурних і суспільно-політичних епох Ю. Станинця й I. Яцканина, з одного боку, ілюструють закономірний і сталий інтерес української літератури до загальнолюдських проблем, незмінність традицій іiі філософічності, що проступає в екзистенціальній проблематиці, психологізмі, 3 другого, - увиразнюють світоглядні засади, ідіостиль обох митців, а також підкреслюють естетичну цінність і актуальність Станинцевої прози.

\section{Література:}

1. Вокович І. Станчук Ю. Подарунок // Народна школа, 1942. № 5. C. $164-165$.

2. Джоганик Я. Три уособлення авторської поетики в сучасній українській літературі Словаччини. Науковий вісник Ужгородського університету. Серія: Філологія. Випуск 8. Ужгород, 2003. С. 84-88.

3. Станинець Ю. Червона йонатаночка: Вибрані твори / Передмова Наталії Ребрик. Ужгород: Гражда, 2011. С. 534-616.

4. Талабірчук O. Horror vacui: Поетика художнього світу Івана Яцканина. Монографія. Ужгород: TIMPANI, 2019. 160 с.

5. Федака Д. Духовні ораниці Юрія Станинця // Наш рідний край. 1999. Річн. 1 (ХУІІІ). № 7. С. 14.

6. Філософія: мислителі, ідеї, концепції: Підручник / В.Г.Кремень, В.В.Ільїн. К.: Книга, 2005. С. 284-309.

7. Яцканин I. Душа в маленькому каштані / Місце проживання. Пряшів: Словацьке видавництво в Братиславі, відділ української літератури в Пряшеві, 1987. $147 \mathrm{c.}$

8. Яцканин I. ... як збиті пси. Пряшів: ЕХСО, 1998. 139 с.

9. Яцканин I. Втеча без вороття. Пряшів: Спілка українських письменників Словаччини. 2010. 214 с. 